\title{
Identification and Validation of Novel Microtubule Suppressors with an Imidazopyridine Scaffold through Structure Based Virtual Screening and Docking.
}

Samia A. Elseginy, ${ }^{1,2}$, A. Sofia F. Oliveira, ${ }^{1,3}$ Deborah K. Shoemark ${ }^{1}$, Richard B. Sessions ${ }^{1^{*}}$

${ }^{1}$ School of Biochemistry, University of Bristol, Biomedical Sciences Building, University Walk, Bristol, BS8 1TD, U.K.

${ }^{2}$ Green Chemistry Department, Chemical Industries Research Division, National Research Centre, 12622, Egypt.

${ }^{3}$ School of Chemistry, University of Bristol, Bristol.BS8 1TS, UK.

*Corresponding Author: Richard B. Sessions

School of Biochemistry, University of Bristol, Biomedical Sciences Building, Bristol, BS8 1TD. UK.

Email: R.Sessions@bristol.ac.uk

Tel: +44 (0)1173312146 


\begin{abstract}
:
Targeting the colchicine binding site of $\alpha / \beta$ tubulin microtubules can lead to suppression of microtubule dynamics, cell cycle arrest and apoptosis. Therefore, development of microtubule (MT) inhibitors is considered a promising route to anticancer agents. Our approach to identify novel scaffolds as MT inhibitors depends on a 3D-structure based pharmacophore approach and docking using three programmes MOE, Autodock and BUDE (Bristol University Docking Engine) to screen a library of virtual compounds. From this work we identified the compound 7-(3-Hydroxy-4-methoxyphenyl)-3-(3-trifluoromethyl-phenyl)-6,7-dihydro-3H-imidazo[4,5-b] pyridin-5-ol (6) as a novel inhibitor scaffold. This compound inhibited several types of cancer cell proliferation at low micromolar concentrations with low toxicity. Compound 6 caused cell cycle arrest in the G2/M phase and blocked tubulin polymerization at low micromolar concentration $\left(\mathrm{IC}_{50}=6.1 \pm 0.1 \mu \mathrm{M}\right)$, inducing apoptosis via activation of caspase 9, increasing the level of the pro-apoptotic protein Bax and decreasing the level of the anti-apoptotic protein Bcl2. In summary, our approach identified a lead compound with potential antimitotic and antiproliferative activity.
\end{abstract}

\title{
1. Introduction:
}

Microtubules (MTs) consist of $\alpha / \beta$ tubulin heterodimers ${ }^{1}$ and are ubiquitous in all eukaryotic cells being the key component of the cytoskeleton. ${ }^{2}$ They play a critical role in many cellular processes, including: cell division in which they assemble to make up the mitotic spindle required for segregation of the chromosomes to the spindle poles and consequent daughter cells; cell proliferation maintenance of cell shape and signal transduction; and MT-motor proteins that transport diverse cellular cargoes. ${ }^{3}$ MTs are characterized by their highly dynamic behaviour, as they switch between periods of elongation and shortening. ${ }^{4}$ Targeting the process of microtubule dynamics is an excellent strategy for chemotherapy and inhibition of MT dynamics and is considered to be one of the most successful approaches in the treatment of cancer. ${ }^{5}$ Microtubule-targeting agents are classified into microtubule destabilizers and microtubule stabilizers according to the mechanism by which they affect microtubule dynamics. ${ }^{6}$ There are four major ligand binding sites identified on the microtubule namely: the vinca and colchicine sites where ligand binding induces microtubule destabilization and the taxane and peloruside /laulimalide sites where binding induces microtubule stabilization. ${ }^{7}$

Taxanes, vinca alkaloids and colchicine all-showed potent inhibition of cancer cell lines. However, colchicine showed limitations as an antitumor agent in clinical trials due to its narrow therapeutic window. ${ }^{8}$ While vinca alkaloids and taxanes are effective, they are also complex natural products that are difficult to synthesise and generally show poor bioavailability. ${ }^{9-10}$ In addition, emergence of resistance to these drugs has been reported. ${ }^{11-12}$ Research has focussed on developing novel 
bioRxiv preprint doi: https://doi.org/10.1101/2021.12.08.471724; this version posted December 9,2021 . The copyright holder for this preprint (which was not certified by peer review) is the author/funder, who has granted bioRxiv a license to display the preprint in perpetuity. It is made available under aCC-BY-ND 4.0 International license.

colchicine site inhibitors (CSI), since the molecular structure of known colchicine-site inhibitors is less complex than that of taxanes and vinca alkaloids. ${ }^{13}$ However, microtubule-destabilizing agents that bind at the colchicine-binding site and reached clinical trials had significant side effects, for example ZD6126 reached phase II trials for metastatic renal cell carcinoma but was withdrawn due to cardiotoxicity, ${ }^{14}$ ABT-751 completed Phase I/II trials but adverse effects were revealed in Phase II. ${ }^{15}$ Despite the great potential of combretastatins and their prodrugs, CA1P and CA4P, these also suffer from drawbacks. ${ }^{16}$ As such, there remains an urgent need to design and discover novel MTs inhibitors based on the colchicine site of $\beta$-tubulin. Therefore, our objective is to identify a novel chemical scaffold to bind the colchicine site that may form the basis of new lead compound which offers promising antimitotic and antiproliferative activity as well as being well-tolerated. Here we have used structure-based pharmacophore virtual screening of the ZINC8 database. ${ }^{17}$ This computational approach represents quick and efficient method in identification novel and diverse scaffold of CSI. Molecular docking was carried out with three programs ${ }^{18}$; the Bristol University Docking Engine (BUDE) ${ }^{19-20}$, AutoDock $4.2^{21}$ and MOE (https://www.chemcomp.com/). Selected hits from this procedure were assessed for antiproliferative activity via their ability to cause mitotic spindle arrest, affect tubulin polymerization and induce apoptosis.

\section{Results and Discussion}

Identifying colchicine binding site inhibitors. A 3D pharmacophore was built based on the analysis of the interaction of colchicine with tubulin; (PDB:1SA0). The derived pharmacophore (Supplementary Figure 1) consists of seven features ${ }^{22}$ comprising the $\mathrm{H}$-bond acceptor centre corresponding to the interaction with Cys $\beta 241$ and the two hydrophobic centres corresponding to interactions with Leuß248, Alaß250, Leuß255, Asn $\beta 258$, Alaß316 and ValßI318 (Zone 2). ${ }^{23}$ One hundred thousand clean and drug like compounds were selected randomly from the ZINC8 database and filtered against the 3D pharmacophore using MOE. This process afforded 2476 compounds matching the pharmacophore. This set of compounds and the native ligand (colchicine) were docked with BUDE, MOE and AutoDock4.2 into the colchicine binding site. MOE and Autodock4.2 are used widely in computational studies, BUDE is an in-house docking program using an empirical free energy forcefield to predict ligand affinities and has been used for inhibitor discovery ${ }^{24,25,26,27,28}$. The predicted binding affinities of colchicine using BUDE, MOE and AutoDock4.2 (-100.27 kJ/mol, $-5.1 \mathrm{kcal} / \mathrm{mol}$ and $-9.52 \mathrm{kcal} / \mathrm{mol})$ respectively, were used as a cut-off for selecting potential hits. The numbers of compounds passing this filter with a binding score better than colchicine were 188, 107 and 226 respectively. Next, we applied the criterion that compounds must be common to two or three of these docked sets. A total of 99 compounds passed this selection step (see Supplementary Data, File S1). A final short list was generated based on visual inspection considering the following criteria: (1) scaffold diversity; (2) 
bioRxiv preprint doi: https://doi.org/10.1101/2021.12.08.471724; this version posted December 9,2021 . The copyright holder for this preprint (which was not certified by peer review) is the author/funder, who has granted bioRxiv a license to display the preprint in perpetuity. It is made available under aCC-BY-ND 4.0 International license.

hydrophobic interactions with zone2 of the binding pocket; (3) at least one hydrogen bond acceptor or donor; (4) containing a methoxy group or 7-membered cyclic ring (most active compounds binding to the colchicine site contain one or both features) and (5) calculated logP $\leq 5$ (see Supplementary Table 1). This filtering gave a short list of 13 compounds. After checking these all passed a PAINS filter (http://zinc15.docking.org/patterns/home/ and http://www.cbligand.org/PAINS/), the compounds were purchased for further activity evaluation (Supplementary Table 1,2).

\section{Biological Evaluation.}

Antiproliferative activity. The anti-proliferation activities of the shortlisted 13 compounds were evaluated against MCF-7, MDA-231, and A549 cancer cells lines using the MTT assay ${ }^{29}$ at $10 \mu \mathrm{M}$ in comparison to paclitaxel (16 $\mathrm{nM})$, employed as a positive control. The results obtained indicated that compounds 6, 8, 9, 13 showed significant anti-proliferative activities against all three cell lines (Figure 1A). Compound 6 caused 50, 40 and 60\% inhibition of MCF-7, A549 and MDA-231 (Figure 1A) cell growth, respectively. Similarly, compound 8 caused 50, 20 and 80\% inhibition of MCF-7, A549 and MDA-231 (Figure 1A) cell growth, respectively. The best activity observed was against MDA-231, a triple negative cell line that is highly aggressive and resistant to treatment. Compounds $\mathbf{9}$ and $\mathbf{1 3}$ caused 50 and $40 \%$ inhibition of all tested cancer cell types (Figure 1A) respectively, with limited toxicity to normal fibroblast F180 cells (Figure 1B). Compounds 6, 8 and $\mathbf{9}$ showed IC $\mathrm{C}_{50}$ values in the 9$20 \mu \mathrm{M}$ range against MCF-7, A549 and MDA-231 (Figure 1C, 1D and Supplementary Table 3).

Inhibition of Mitotic Spindle Formation. The mechanism of action of the candidates $\mathbf{6 , 8}$ and $\mathbf{9}$ on tubulin organization into mitotic spindles during cell division was investigated using an immunofluorescence assay. ${ }^{30}$ Compounds 6,8 and $\mathbf{9}$ caused the formation of classical multipolar spindle profiles (Figure 2A), similar to the positive controls paclitaxel and colchicine. These results indicated that compounds 6, 8 and 9 caused inhibition of tubulin assembly with irregular morphology, showing typical mitotic arrest.

Tubulin Polymerization Assay in vitro. Microtubule polymer solutions scatter light in a concentration- dependent manner. ${ }^{31}$ This behaviour was used to monitor the effect of ligands on microtubule polymerization (Figure 2). Compounds 6, 8 and $\mathbf{9}$ at $15 \mu \mathrm{M}$ and paclitaxel and colchicine at $3 \mu \mathrm{M}$ were incubated with unpolymerized tubulin protein at $37^{\circ} \mathrm{C}$ for $24 \mathrm{hrs}$. The tubulin polymerization activities were determined by measuring the fluorescence and area under the curve (AUC) (Figure 2B,2C). In the control experiment, the fluorescence increased with time until reaching a plateau phase with an AUC around 6000 RFU (Figure 2B). Paclitaxel caused an increase in the AUC by $\sim 1.3$ fold, while colchicine caused a decrease in the AUC by $\sim 1.3$ fold when compared to the 
bioRxiv preprint doi: https://doi.org/10.1101/2021.12.08.471724; this version posted December 9,2021 . The copyright holder for this preprint (which was not certified by peer review) is the author/funder, who has granted bioRxiv a license to display the preprint in perpetuity. It is made available under aCC-BY-ND 4.0 International license.

negative control. Notably, compound $\mathbf{6}$ and $\mathbf{8}$ caused inhibition of tubulin polymerization like colchicine, while compound 9 showed slight enhancement of tubulin polymerization (Figure 2B, 2C).

Tubulin polymerization inhibition mechanism in cells: An ELISA assay was used to measure tubulin polymerization in MCF7 cells in the presence of compounds $\mathbf{6 , 8}$ and $\mathbf{9}$. The results are shown in (Figure 3) and indicate that $\mathbf{6}$ behaves like colchicine as a suppressor of microtubule polymerization, while 8 and 9 enhance polymerization. These results are in reasonable accordance with the in-vitro tubulin polymerization assay results. $I C_{50}$ values of Compounds 6,8 and 9 required to inhibit tubulin polymerization were $6.1 \pm 0.1,13.1 \pm 0.3$ and $12.8 \pm 0.2 \mu \mathrm{M}$ respectively (Figure 4 , Table 1 ). Compound 6 was selected for further investigation due to its low toxicity on normal cells while affording good potency against cancer cells (particularly MCF7 cells). It also showed the best activity in the tubulin polymerization assays. Although the $\mathrm{IC}_{50}$ of compound 6 is higher than colchicine $\left(6.1 \pm 0.1 \mu \mathrm{M}\right.$ and $\mathrm{IC}_{50}$ $1.4 \pm 0.02 \mu \mathrm{M}$ respectively, Table 1 ) the low cytotoxicity of this compound suggests that it is a promising lead-molecule and scaffold for drug development.

Compound 6 Inhibited Cell Cycle Progression at G2/M and induced apoptosis. Cell cycle analysis was performed to determine at which phase compound $\mathbf{6}$ exerted its antimitotic effect. MCF7 cells were treated with compound 6 at its $\mathrm{IC}_{50}$ concentration $(6 \mu \mathrm{M})$ and $0.1 \%$ DMSO as control and incubated for $24 \mathrm{hr}$, followed by measuring cell cycle distribution by flow cytometry. The results showed that the antimitotic activity of compounds 6 was through apoptosis. Compound 6 caused a 10 -fold increase in cell populations at the G2/M compared to control (Figures 5A-C, Supplementary Table4). The apoptotic activity of compound $\mathbf{6}$ was further evaluated by propidium iodide (PI) and annexin-V-FITC labeling assay on MCF-7 cells and using flow cytometry analysis ${ }^{32}$. Compound 6 caused an 84-fold increase in the late stage of cellular apoptosis compared to the negative control (Figures 5D-F). Furthermore, the compound also caused a decrease in early apoptosis by 11 -fold compared to negative control (Figures 5D-F).

Compound 6 acts by a dual apoptosis mechanism. The apoptotic effect of compound 6 was determined by measuring caspase 9 levels. Caspase 9 initiates apoptosis by activating a cascade of intracellular events. ${ }^{33-34}$ MCF7 cancer cells were treated with compound 6 at $6 \mu \mathrm{M}$ for $24 \mathrm{~h}$. The level of caspase 9 was then measured by Enzyme Linked Immuno-Sorbent assay (ELISA) analysis. Compound 6 showed an increase in the level of caspase- 9 in treated cells by 7.6-fold compared to control-vehicletreated cells (Table 2). The Bcl2 family of proteins play a crucial role in regulating mitochondrial apoptosis by either increasing the level of $\mathrm{Bcl} 2$ anti-apoptotic proteins or downregulating the level of Bax, a pro-apoptotic protein. Hence, cancer cells may develop resistance to apoptosis by changing the level of the Bcl2 and Bax protein expression. The effect of compound 6 on the balance of Bcl2/Bax proteins in MCF7 cancer cells was investigated. The results showed that compound 6 increased the 
bioRxiv preprint doi: https://doi.org/10.1101/2021.12.08.471724; this version posted December 9,2021 . The copyright holder for this preprint (which was not certified by peer review) is the author/funder, who has granted bioRxiv a license to display the preprint in perpetuity. It is made available under aCC-BY-ND 4.0 International license.

level of the pro-apoptotic protein Bax by 7.2 fold compared to the control, and at the same time decreased the level of the anti-apoptotic protein Bcl2 by 2.7 fold (Table 2 ).

Compound verification. ${ }^{1} \mathrm{H}$ NMR spectra of compound 6 (Figure 6), compounds 8 and 9 (Supplementary Figures S3, S5) were measured to confirm the chemical structures. Likewise, molecular weights were confirmed by mass spectroscopy for compound $6 \mathrm{MS} \mathrm{m/z}=404.36\left[\mathrm{M}^{+}+1\right]$ and compound $8 \mathrm{MS} \mathrm{m} / \mathrm{z} 497.37\left[\mathrm{M}^{+}+1\right]$ (Supplementary Figures 2,4 respectively).

Computational Modelling. To further elucidate the interactions between compounds $\mathbf{6 , 8}$ and $\mathbf{9}$ and tubulin, the binding mode of the three compounds within the colchicine binding site was investigated. The results of docking 6, 8 and 9 are summarized in Supplementary Table 5. The docking study revealed that the compounds fitted comfortably within the hydrophobic pocket of $\beta$-tubulin, making hydrophobic interactions with the hydrophobic residues lining zone 2 of the colchicine binding pocket, namely Leuß242, Leuß248, Alaß250, Leuß255, ValßI315, Alaß316 and Ileß378. The trifluoro phenyl ring of compound $\mathbf{6}$ occupied the same position as trimethoxy phenyl ring of colchicine, facilitating hydrophobic interactions with key residues (Figure 7A). In the case of compound $\mathbf{8}$, the 4-fluoro phenyl ring occupied the position of trimethoxy phenyl ring of colchicine and the dimethoxy quinoline ring adopted an analogous position as the tropone ring of colchicine (Figure 7B). However, compound 9 showed a different binding mode with the dimethoxy quinoline ring positioned where the trimethoxy phenyl ring of colchicine, and the 4-fluoro phenyl group of tropone (6C) reside. The three compounds showed strong $\mathrm{H}$-bonds, as the $\mathrm{OH}$ of compound $\mathbf{6}$ served as $\mathrm{H}$ donor and formed an $\mathrm{H}$-bond with Thro179 and $\mathrm{OCH}_{3}$ formed an $\mathrm{H}$-bond with $\mathrm{NH}-\mathrm{Ala \beta 2} 20$ (Figure 8, and Supplementary Table 5). Both compounds 8 and 9 formed H-bonds with Sera178, and Cys 3241 . (Figure 8, and Supplementary Table 5). The trifluoro phenyl group of compound 6 faced SH-Cys $\beta 241$, allowing the lone pair of electrons of the sulphur to interact with the pi cloud of the aromatic ring $(\mathrm{SH}---\pi) \cdot{ }^{35}$ Analyses of the docking results indicates that the hydrophobic interactions of compounds 6,8 and 9 predominate while $\mathrm{H}$-bonds help in the proper orientation of the compounds within the binding pocket.

Molecular dynamics simulations were run for 50 ns to investigate the stability of the tubulin-ligand complexes. The Root Mean Square Deviation (RMSD) and Root Mean Square Fluctuation (RMSF) values of all protein/ligand complexes were plotted in (Supplementary Figure S6, S7). Plotting RMSD versus time showed that the tubulin complexes reached equilibrium for this timescale around $10 \mathrm{~ns}$ (Figure S6). The average RMSD values (Supplementary Table S6) of tubulin alone and tubulin/ligand complexes range between 0.25 and $0.32 \mathrm{~nm}$ ). The RMSF of the atoms of each residue in the complexes are represented in Figure S7, Table S6). The three compounds 6, 7 and 8 reduce the fluctuation of residues 242-258 and residues 352-355 which include the key residues of the active site; Leuß242, Leuß248, Alaß250, Leuß252, Leuß255 and Asnß258, Lys $\beta 352$, Thrß353, Alaß354, Valß355, consistent 
with stabilizing interactions between the ligand and these residues. The RMSD and RMSF results (Supplementary Figures 6,7) indicate compounds 6, 8 and 9 remain close to the docked pose site and reduce the RMSF of key residues in comparison to colchicine.

Conclusion: In this paper we have used computational methods to identify inhibitors and modulators of tubulin polymerisation. Firstly, pharmacophore matching was used to filter out some $98 \%$ of compounds from a library of 100,000 available compounds. Docking of these 2746 matched compounds was performed using three different methods and the following filters applied: compounds must be predicted to bind better than colchicine in the given method; compounds must be selected by all three docking methods. Thirteen compounds were selected by inspection for testing from the surviving 99 compounds and these were purchased for experimental testing. Of these, three had low micromolar activity in the polymerisation assay and low toxicity. Testing these in the cell assays showed that 6 was the most active compound with minimal toxicity. Further experiments with 6 showed that it disrupted spindles in the mitotic cells giving a phenotype similar to colchicine. FACS cell cycle analysis showed that 6 arrests the cell cycle at G2/M phase and induces late apoptosis via upregulating caspase-9 and Bax, while downregulating Bcl2. The activity of molecule 6 against cancer cells, coupled with its low cytotoxicity to normal fibroblasts, provides a promising start-point for medicinal chemistry development. Varying both phenyl groups may yet improve potency and selectivity towards a well-tolerated anticancer therapeutic.

\section{Experimental Section:}

Chemistry: $1 \mathrm{H}$ NMR spectra were recorded on a Bruker spectrometer at $500 \mathrm{MHz}$. Chemical shifts are expressed in parts per million (ppm) relative to tetramethylsilane and coupling constants ( $\mathrm{J}$ values) are represented in Hertz $(\mathrm{Hz})$ and the signals are designated as follows: s, singlet; $d$, doublet; t, triplet; $m$, multiplet. Mass spectroscopic data were obtained through Electrospray ionization (ESI) mass spectrum.

7-(3-Hydroxy-4-methoxy-phenyl)-3-(3-trifluoromethyl-phenyl)-6,7-dihydro-3H-imidazo[4,5-b] pyridin-5-ol (Compound 6). ${ }^{1} \mathrm{H}$ NMR (DMSO-d6) $\delta: 2.72(\mathrm{~m}, 1 \mathrm{H}, \underline{\mathrm{H}}-\mathrm{CH}), 3.12(\mathrm{~m}, 1 \mathrm{H}, \mathrm{H}-\mathrm{C}-\underline{\mathrm{H}}$ ), 3.75 (s , $\left.3 \mathrm{H}, \mathrm{OCH}_{3}\right), 4.23(\mathrm{~m}, 1 \mathrm{H}, \mathrm{CH}), 6.25(\mathrm{~m}, 2 \mathrm{H}, \mathrm{ArH}), 6.80(\mathrm{~d}, 1 \mathrm{H}, \mathrm{J}=8, \mathrm{ArH}), 7.54(\mathrm{~d}, 1 \mathrm{H}, \mathrm{J}=6.5, \mathrm{ArH}), 7.82$ $(\mathrm{m}, 4 \mathrm{H}, \mathrm{ArH}$, imidazole $\mathrm{C} \underline{\mathrm{H}}), 8.60(\mathrm{~s}, 1 \mathrm{H}, \mathrm{OH}), 10.2(\mathrm{~s}, 1 \mathrm{H}, \mathrm{OH})$. MS analysis for $\mathrm{C}_{20} \mathrm{H}_{16} \mathrm{~F}_{3} \mathrm{~N}_{3} \mathrm{O}_{3}$ Calcd mass 403.11, found (m/z, ESI+) $\left(\mathrm{M}^{+}+1\right)$ : 404.36 .

$\mathrm{N}$-(3,4-difluorophenyl)-2- [3-(4-fluorobenzoyl)- 6,7-dimethoxy -4-oxoquinolin-1-yl] acetamide (Compound 8). ${ }^{1} \mathrm{H}$ NMR (DMSO-d6) $\delta: 3.85\left(\mathrm{~s}, 6 \mathrm{H}, 2 \mathrm{OCH}_{3}\right), 5.23\left(\mathrm{~s}, 2 \mathrm{H}, \mathrm{CH}_{2}\right) 7.02(\mathrm{~s}, 1 \mathrm{H}, \underline{\mathrm{ArH}}), 7.32(\mathrm{~m}$, $3 \mathrm{H}, \mathrm{ArH}), 7.45$ (q $, 1 \mathrm{H}, \mathrm{ArH}), 7.62(\mathrm{~s}, 1 \mathrm{H}, \mathrm{ArH}), 7.83(\mathrm{~m}, 3 \mathrm{H}, \mathrm{Ar}-\mathrm{H}), 8.33$ (s, 1H, quinolone 2-CH), 10.80 
bioRxiv preprint doi: https://doi.org/10.1101/2021.12.08.471724; this version posted December 9, 2021. The copyright holder for this preprint (which was not certified by peer review) is the author/funder, who has granted bioRxiv a license to display the preprint in perpetuity. It is made available under aCC-BY-ND 4.0 International license.

(s, $1 \mathrm{H}, \mathrm{NH}$ of acetamide). MS analysis for $\mathrm{C}_{26} \mathrm{H}_{19} \mathrm{~F}_{3} \mathrm{~N}_{2} \mathrm{O}_{5}$ Calcd mass 496.12 , found $(\mathrm{m} / \mathrm{z}, \mathrm{ESI}+)\left(\mathrm{M}^{+}+1\right)$ : 497.37

$N$-(4-fluorophenyl) 2- [6,7- dimethoxy-3 -(4-methoxybenzoyl) -4-oxoquinolin-1-yl]- acetamide (Compound 9). ${ }^{1} \mathrm{H}$ NMR (DMSO-d6) $\delta: 3.85\left(\mathrm{~s}, 9 \mathrm{H}, 3 \mathrm{OCH}_{3}\right), 5.24\left(\mathrm{~s}, 2 \mathrm{H}, \mathrm{CH}_{2}\right) 7.02(\mathrm{~m}, 3 \mathrm{H}, \underline{\mathrm{ArH}}), 7.2(\mathrm{t}$, $2 \mathrm{H}, \mathrm{ArH}), 7.60(\mathrm{~m}, 3 \mathrm{H}, \mathrm{ArH}), 7.74(\mathrm{~d}, 2 \mathrm{H}, \mathrm{ArH}), 8.3(\mathrm{~s}, 1 \mathrm{H}$, quinolone 2-CH), $10.62(\mathrm{~s}, 1 \mathrm{H}, \mathrm{NH}$ of acetamide).

Computational Methods. Protein and database preparation: The X-ray crystal structure of $\alpha / \beta$ tubulin in complex with colchicine-DAMA (PDB code: 1SA0) was download from protein data bank https://www.rcsb.org/ and used for virtual screening. Chains $C$ and D were removed, the protein structure was prepared by inserting the missing loop regions using MODELLER ${ }^{36}$ via the UCSF Chimera graphical interface ${ }^{37}$ Hydrogen atoms were added, and water molecules were removed using MOE. A library of 100, 000 compounds was randomly selected from the clean, druglike subset of the ZINC15 database was used for virtual screening. The compounds were saved as mdb format files by MOE. A 3D structure-based pharmacophore was constructed from the tubulin-colchicine complex 1SAO). using the Protein Ligand Interaction Fingerprints (PLIF) application implemented in MOE. The pharmacophore model compromises seven features. Three $\mathrm{H}$-bond acceptors and one $\mathrm{H}$-bond donor (F1, F2, F7 and F5) respectively. Two hydrophobic centres (F4 and F6), and an aromatic centre (F3). These represent: i) the two acceptors F1 and F7 corresponding to interaction with Cys $\beta 241$, ii) The third acceptor (F2) corresponding to interaction of Val $\alpha 181$, iii) aromatic centre (F3), iv) two hydrophobic centres (F4 and F6) corresponding to hydrophobic interaction with Leuß248, Alaß250, Leuß255, Asn 3258 , Alaß316 and Valß1318. The pharmacophore model was employed as a search query to identify commercial compounds targeting the colchicine binding site matching at least 4 of the 7 pharmacophore features.

Molecular docking was performed using three programs: BUDE, AutoDock and MOE. Validation of the screening model and applied protocol was carried out by re-docking the native ligand in the binding site of the tubulin protein. The RMSD value was then calculated with respect to the co-crystallized ligands. An RMSD value equal to, or less than, $1.0 \AA$ fetween the X-Ray structure and the best-scored conformations of the native ligand, the docking process was considered successful. ${ }^{38}$ The native ligand (colchicine) was removed from binding site and was re-docked into the active site of 1SA0. The RMSD between the re-docked and co-crystal ligand is less than $1 \AA$ for the three programs, indicating a consensus of the methods and consistency of pose prediction. The predicted binding energies for colchicine re-docked by BUDE, AutoDock and MOE were $-100.27 \mathrm{~kJ} / \mathrm{mol},-9.52 \mathrm{kcal} / \mathrm{mol}$ and -5.1 $\mathrm{kcal} / \mathrm{mol}$ ) respectively. 
bioRxiv preprint doi: https://doi.org/10.1101/2021.12.08.471724; this version posted December 9,2021 . The copyright holder for this preprint (which was not certified by peer review) is the author/funder, who has granted bioRxiv a license to display the preprint in perpetuity. It is made available under aCC-BY-ND 4.0 International license.

Virtual screening with BUDE. Molecular docking was performed using the Bristol University Docking Engine (BUDE) for the compounds filtered by the 3D pharmacophore into the tubulin-colchicine binding site. The BUDE search area was defined as grid centred on the native ligand $(X=42.848$, $\mathrm{Y}=52.376, \mathrm{Z}=-8.531)$. BUDE is a rapid rigid-body docking program, hence ligand flexibility is achieved by docking multiple conformers of each ligand. All compounds with a predicted binding energy more favourable than that for colchicine were selected ( 177 compounds with binding energy $\leq-100 \mathrm{~kJ} / \mathrm{mol}$ ).

Virtual screening with AutoDock 4.2. The native ligand was removed from the crystal structure (PDB:1SA0) and AutoDock.4.2 used to convert both protein structure and the native ligand separately into PDBQT format. Polar hydrogen atoms and Kollman charges were assigned to the protein. Gasteiger partial charges were assigned to the ligand and non-polar hydrogen atoms merged with their heavy atoms Rotatable bonds in the ligand were defined using an AutoDock utility, AutoTors. The grid box was placed at the centroid of native ligand $(X=42.845, Y=52.376$ and $Z=-8.531)$, the box size was $100 \times 100 \times 100 \AA \AA$ with a 0.2 A grid spacing and the grid map was calculated using Autogrid tool and saved as a gpf file. Docking was performed using the Lamarckian genetic algorithm, each docking experiment was performed 100 runs, the configuration file saved as dpf format. Raccoon was used to prepare all the 2476 ligands to perform docking with Autodock 4.2, the Raccoon software splits the multi-structure files of the ligands to separate PDBQT input files and generate configuration files and scripts for both and Autodock. The results were sorted according to the lowest predicted binding energy. 226 compounds had predicted binding energies $\leq-9.52 \mathrm{kcal} / \mathrm{mol}$ (the colchicine binding energy calculated with AutoDock).

Virtual screening with MOE. The same protein (1SA0) and set of ligands from the 3D pharmacophore filtration and converted to mdb format. MOE was used to add hydrogen atoms to the ligands and energy minimised until the gradient of energy with respect to coordinates fell below $0.05 \mathrm{kcal} \mathrm{mol}^{-1} \AA^{-}$ ${ }^{1}$ under the was MMFF94X force field. The binding site was defined as the colchicine site. Ligands were docked using the Triangle Matcher method with the London dG scoring function. Refinement was performed using the rescoring affinity dG method. The lowest energy pose was chosen for each docked compound yielding 188 compounds with a binding energy lower than colchicine (-5.1 $\mathrm{kcal} / \mathrm{mol})$.

Selection of compounds for testing. Next the requirement for a compound to be present in at least two docking search results was applied, giving 99 compounds (Supplementary Data File S1). These the 99 compounds were re-docked with MOE to allow a consistent set for visualization with Pymol. ${ }^{39}$ Further selection by inspection was performed as described in Results based on (i) a favourable predicted binding energy (ii) a good pose i.e., the presence of interactions with key binding-site residues; (iii) ensuring test set represents as much chemical diversity as possible. This process gave a 
bioRxiv preprint doi: https://doi.org/10.1101/2021.12.08.471724; this version posted December 9, 2021. The copyright holder for this preprint (which was not certified by peer review) is the author/funder, who has granted bioRxiv a license to display the preprint in perpetuity. It is made available under aCC-BY-ND 4.0 International license.

short list of 13 compounds (Supplementary Table 1,2). The shortlisted hits were screened for pan assay interference compounds (PAINS) using the online PAINS filters at http://zinc15.docking.org/patterns/home/ and http://www.cbligand.org/PAINS/. The 13 compounds passed both filters. and were purchased from MCULE (USA) for experimental testing.

Molecular Dynamics (MD) simulations.MD simulations of the three docked complexes of tubulin (PDB:1SA0) with 6, 8 and 9 were carried out for 50 ns using GROMACS $5.1 .2^{40}$ as follows. Pdb2gmx was used to add hydrogen atoms to the protein consistent with $\mathrm{pH} 7$ and generate a topology file under the Amber99-SB-ildnb force field. ${ }^{41}$ Acpype ${ }^{42}\{\mathrm{Da}$ Silva, $2012 \# 49\}$ was used to generate topology files of the compounds 6,8 and 9 under the GAFF force field..$^{43}$ The ligand and protein complexes were centred in a cubic box with a minimum margin of $1 \mathrm{~nm}$ and filled with TIP3P water. The system was neutralized by adding sodium and chloride ions to give an ionic strength of $0.15 \mathrm{M}$. The energy minimization (5000 steps) was conducted using steepest descents. All simulations were performed as NPT ensembles at $310 \mathrm{~K}$ under periodic boundary conditions. The Particle Mesh Ewald (PME) method was used for calculating long range electrostatics, and Van der Waals (VdW) interactions. The cut-off distance for the short-range $\mathrm{VdW}$ and Coulombic interactions was set to $1.2 \mathrm{~nm} .{ }^{44}$ Pressure was controlled by the Parrinello-Rahman barostat and temperature by the Nosé-Hoover thermostat. The simulations were integrated with a leap-frog algorithm over a $2 \mathrm{fs}$ time step, constraining bond vibrations with the P-LINCS method. Molecular dynamics simulations were carried out for $50 \mathrm{~ns}$ on Blue Crystal, the University of Bristol's high-performance computing machine. The Root Mean Square Deviation and Fluctuation (RMSD/F) analyses were carried out using GROMACS tools and Xmgrace, molecular graphics manipulations and visualizations were performed using VMD-1.9.1 ${ }^{45}$ and Pymol ${ }^{39}$.

\section{Biological Methods.}

Cell culture and maintenance. Breast cancer cell lines including breast cancer cell lines (MCF-7), triple-negative breast cancer (MDA-231), adenocarcinomic human alveolar basal epithelial cells (A549), and normal fibroblast cells (F180) were cultured in Roswell Park Memorial Institute media (RPMI, Sigma-Aldrich, St. Louis, MO, USA) supplemented with $10 \%$ fetal bovine serum, and $1 \%$ penicillin/streptomycin. All cell lines were purchased from the European Collection of Cell Cultures (ECACC, UK). Cell lines were incubated at $37^{\circ} \mathrm{C}$ in a humidified incubator containing $5 \% \mathrm{CO}_{2}$.

Antiproliferative and cytotoxic activity. The antiproliferative activity of compounds 1-13 were evaluated by testing their effects on the aforementioned cell lines 3-(4, 5-dimethyl thiazolyl-2)-2,5diphenyltetrazolium bromide (MTT) assay as described before ${ }^{17}$. The cancer cell lines were seeded as 
bioRxiv preprint doi: https://doi.org/10.1101/2021.12.08.471724; this version posted December 9,2021 . The copyright holder for this preprint (which was not certified by peer review) is the author/funder, who has granted bioRxiv a license to display the preprint in perpetuity. It is made available under aCC-BY-ND 4.0 International license.

$1 \times 10^{4}$ cells per well in 96-well flat bottom plates for $24 \mathrm{~h}$. The cells were then treated with $10 \mu \mathrm{M}$ of compounds $1-13$ and incubated for $48 \mathrm{~h}$ at $37^{\circ} \mathrm{C}$ in a humidified incubator containing $5 \% \mathrm{CO}_{2}$. Paclitaxel and $0.1 \%$ DMSO were employed as positive and negative controls, respectively. The culture media was then removed, washed, and then incubated with $200 \mu \mathrm{l}$ culture media containing $0.5 \mathrm{mg} / \mathrm{ml} \mathrm{MTT}$ for $2 \mathrm{hr}$. The blue formazan crystals, converted from the yellow MTT by viable cells, were dissolved by adding $200 \mu \mathrm{I}$ DMSO and measured spectrophotometrically at $570 \mathrm{~nm}$ in a microplate reader (ThermoScientific, Vantaa, Finland). Cell viability was calculated, using the following formula: \% of living cells $=(\mathrm{OD}$ experimental) $/(\mathrm{OD}$ control $) \times 100$, while $\%$ of cell death was calculated by subtracting the living cells from the total number of cells. To determine the $\mathrm{IC}_{50}$ of the active compounds, the cells were treated with different concentrations $2.5,5,10,20 \mu \mathrm{M}$ of compounds (6, 8 and $\mathbf{9})$.

Immunofluorescence assay. A549 cells $\left(5 \times 10^{4} /\right.$ well) were plated on coverslips in 6-well plates and treated with compounds 6,8 and 9 at concentrations of 16,13 , and $9 \mu \mathrm{M}$, respectively for $24 \mathrm{~h}$. Paclitaxel $(14 \mathrm{nM})$ and Colchicine $(0.1 \mu \mathrm{M})$ used as positive controls while $0.1 \%$ DMSO used as a negative control. The cells were then rinsed twice with PBS, fixed with 3.7\% paraformaldehyde, and permeabilized with $0.1 \%$ Triton X-100. The cells were blocked with 1\% BSA in PBS for $1 \mathrm{~h}$ prior to incubation with anti- $\beta$-tubulin mouse monoclonal antibody (\#86298, Cell Signaling, San Francisco, CA, USA) overnight at $4^{\circ} \mathrm{C}$. The cells were washed with PBS for $1 \mathrm{~h}$ in the dark, and then incubated with Alexa Fluor ${ }^{\circledR} 488$ secondary antibodies (Abcam). The cellular microtubules were observed with a fluorescence microscope (Olympus BX43, Japan).

In vitro tubulin polymerization assay. Tubulin polymerization was analyzed in vitro using a Tubulin Polymerization Assay kit (Cytoskeleton, Denver, CO). Briefly, $2 \mathrm{mg} / \mathrm{ml}$ Porcine tubulin was dissolved in buffer 1 (80 mM PIPES, 2 mM MgCl $2,0.5$ mM EGTA pH 6.9, $10 \mu \mathrm{M}$ fluorescent reporter, 1 mM GTP, $15 \%$ glycerol). This solution was transferred to a pre-warmed 96 -well plate and treated with $15 \mu \mathrm{M}$ of the test compounds $\mathbf{6 , 8}$ and $\mathbf{9}$. Colchicine and paclitaxel at $3 \mu \mathrm{M}$ were employed as positive controls, while $0.1 \%$ DMSO treated-cells were employed as a negative control. Tubulin polymerization was monitored at $37^{\circ} \mathrm{C}$ for 60 min using fluorescence microscopy. The reading speed was programmed at $1 \mathrm{cycle} / \mathrm{min}$ with excitation and emission wavelengths of 360 and $450 \mathrm{~nm}$, respectively, using the Varioskan Flash spectral scanning multimode reader (Thermo Fisher Scientific). The 100\% polymerization value was defined as the area under the curve (AUC) of the untreated control.

Extraction of soluble and polymerized tubulin fractions. Extraction was done using the protocol previously reported ${ }^{46}$ After treatment with drugs for $24 \mathrm{~h}$, medium containing cells in suspension was recovered and pooled with adherent cells scraped in PBS pre-warmed at $37^{\circ} \mathrm{C}$. After centrifugation 5 min at $400 \times \mathrm{g}$, wash with PBS, cells were extracted for 5 min with pre-warmed at $37^{\circ} \mathrm{C}$ microtubulestabilizing buffer (0.1 M PIPES pH 6.9, 14.5\% glycerol, 0.5\% Triton X-100, 20 mM EGTA and 5 mM 
bioRxiv preprint doi: https:/doi.org/10.1101/2021.12.08.471724; this version posted December 9, 2021. The copyright holder for this preprint (which was not certified by peer review) is the author/funder, who has granted bioRxiv a license to display the preprint in perpetuity. It is made available under aCC-BY-ND 4.0 International license.

$\mathrm{MgCl} 2$ ) containing Complete (Sigma FAST Protease Inhibitor Cocktail Tablet) and $10 \mathrm{ng} / \mathrm{ml}$ paclitaxel (Sigma). After centrifugation at $20000 \mathrm{xg}$ for $10 \mathrm{~min}$ at $25^{\circ} \mathrm{C}$, supernatants containing soluble fractions were transferred to a new tube, while polymerized fractions in pellets were recovered by incubation in RIPA buffer for $45 \mathrm{~min}$ on ice followed by centrifugation for $10 \mathrm{~min}$ at $20000 \mathrm{x}$. The total protein content in the samples was determined using DC protein assay kit (Bio-Rad, Hercules, CA, USA). Equivalent aliquots from polymeric fractions were measured using Human Beta-tubulin ELISA Kit (Abcam) following the manufacturer's instructions.

Determination of the $I C_{50}$ of compound 6,8 and 9 . The IC $C_{50}$ of compounds 6,8 and 9 required to inhibit tubulin polymerization was measured using ELISA kit (Cat. \# BK011P, Cytoskeleton, Denver, CO) with tubulin protein (Cat. \#T240-DX, Cytoskeleton, Denver, CO) according to the manufacturer's instructions. ${ }^{47}$

Cell Cycle analysis. MCF7 cancer cells were treated with compounds 6 at $6 \mu \mathrm{M}$ for $24 \mathrm{~h}$. DMSO was employed as vehicle control. The cells were harvested, centrifuged, and the cell pellets were fixed with $70 \%$ ethanol on ice for $15 \mathrm{~min}$. The fixed pellets were incubated with propidium iodide (SigmaAldrich, St. Louis, MO, USA), staining solution ( $50 \mathrm{mg} / \mathrm{mL}$ PI, $0.1 \mathrm{mg} / \mathrm{mL}$ RNaseA, $0.05 \%$ Triton X-100) for $1 \mathrm{~h}$ at room temperature. Cell cycle was assessed by Gallios flow cytometer (Beckman Coulter, Brea, CA, USA).

Apoptosis assay. The apoptosis assay was carried out using the FITC Annexin- V/PI commercial kit (Becton Dickenson, Franklin Lakes, NJ, USA), MCF-7 cells were treated with compound 6 at $6 \mu \mathrm{M}$ for $24 \mathrm{hr}$. 0.1\% DMSO was used as negative control. Treated and control cells were stained using V/PI apoptosis kit. Samples were analysed by fluorescence-activated cell sorting (FACS) using flow cytometer run over one hour. Data were analysed using Kaluzav 1.2 (Beckman Coulter). ${ }^{48}$

Caspase-9 assay. MCF-7 cells were incubated without and with $6 \mu \mathrm{M}$ of compound 6 for $24 \mathrm{hr}$. The cells were washed in phosphate buffered saline and cell lysates were collected and level of caspase 9 was determined using ELISA kit (Cat. \# EIA-4860, Invitrogen, Carlsbad, CA, USA), and according to manufacturer instruction https://www.thermofisher.com/elisa/product/Caspase-9-Human-ELISA-

\section{Kit/BMS2025}

Determination of the effect compound 6 on BAX and Bcl-2 protein levels. MCF-7 cells, which were grown in RPMI 1640 containing 10\% fetal bovine serum. The cells were treated with compound 6 at 6 $\mu \mathrm{M}$ for $24 \mathrm{~h}$. The cells were then lysed using cell extraction buffer. The collected lysate was diluted in standard diluent buffer and the levels of $\mathrm{Bax}$ and $\mathrm{Bc} / 2$ were measured as previously reported. ${ }^{49}$ 
Statistical analysis. Data were plotted using GraphPad Prism (5.04, La Jolla, CA, USA). A two-way analysis of variance (ANOVA) using Bonferroni's Multiple Comparison Test was performed and shown as the mean \pm SEM of three independent replicates. The statistical significance level was set at $P<0.05$.

\section{ASSOCIATED CONTENT:}

\section{Supporting Information:}

ZINC ID lists (Supplementary files 1,2). Chemical structure and physical properties of shortlisted compounds and $\mathrm{IC}_{50}$ of the promising compounds against cancer cell lines and effect of compound 6 on phases of MCF7 cell cycle (Supplementary Tables 1-4). Molecular modelling and molecular dynamics result (Supplementary Tables 5,6). Schematic view of pharmacophore structure-based virtual screening, ${ }^{1} \mathrm{HNMR}$ spectra of compounds 8 and $\mathbf{9}$. RMSD and RMSF of compounds $6,8,9$ and colchicine in complex with tubulin during $50 \mathrm{~ns}$.

\section{Acknowledgments:}

We thank the Advanced Computing Research Centre at the University of Bristol for provision of HighPerformance Computing using BlueCrystal supercomputers. ASFO, DKS and RBS thank BrisSynBio (EPSRC/BBSRC: BB/L01386X/1) for support. We also acknowledge Dr. Esam Rashwan, head of confirmatory diagnostic unit, Vacsera-Egypt, for helping in performing the biological assays. We thank Dr. Amaurys Avila Ibarra for discussions and assistance with software.

\section{References:}

1. Erickson, H. P.; O'Brien, E. T., Microtubule dynamic instability and GTP hydrolysis. Annual review of biophysics and biomolecular structure 1992, 21 (1), 145-166.

2. Prassanawar, S. S.; Panda, D., Tubulin heterogeneity regulates functions and dynamics of microtubules and plays a role in the development of drug resistance in cancer. Biochemical Journal 2019, 476 (9), 1359-1376. 
3. Hammond, J. W.; Cai, D.; Verhey, K. J., Tubulin modifications and their cellular functions. Current opinion in cell biology 2008, 20 (1), 71-76.

4. Nogales, E.; Wang, H.-W., Structural intermediates in microtubule assembly and disassembly: how and why? Current opinion in cell biology 2006, 18 (2), 179-184.

5. Mahindroo, N.; Liou, J.-P.; Chang, J.-Y.; Hsieh, H.-P., Antitubulin agents for the treatment of cancer-a medicinal chemistry update. Expert Opinion on Therapeutic Patents 2006, 16 (5), 647-691. 6. Jordan, M. A.; Kamath, K., How do microtubule-targeted drugs work? An overview. Current cancer drug targets 2007, 7 (8), 730-742.

7. Dumontet, C.; Jordan, M. A., Microtubule-binding agents: a dynamic field of cancer therapeutics. Nature reviews Drug discovery 2010, 9 (10), 790-803.

8. Lu, Y.; Chen, J.; Xiao, M.; Li, W.; Miller, D. D., An overview of tubulin inhibitors that interact with the colchicine binding site. Pharmaceutical research 2012, 29 (11), 2943-2971.

9. Tischer, J.; Gergely, F., Anti-mitotic therapies in cancer. Journal of Cell Biology 2019, 218 (1), 10-11.

10. Yin, S.; Bhattacharya, R.; Cabral, F., Human mutations that confer paclitaxel resistance. Molecular cancer therapeutics 2010, 9 (2), 327-335.

11. Henriquez, F. L.; Ingram, P. R.; Muench, S. P.; Rice, D. W.; Roberts, C. W., Molecular basis for resistance of Acanthamoeba tubulins to all major classes of antitubulin compounds. Antimicrobial agents and chemotherapy 2008, 52 (3), 1133-1135.

12. McGrogan, B. T.; Gilmartin, B.; Carney, D. N.; McCann, A., Taxanes, microtubules and chemoresistant breast cancer. Biochimica et Biophysica Acta (BBA)-Reviews on Cancer 2008, 1785 (2), 96-132.

13. Li, D. D.; Qin, Y. J.; Zhang, X.; Yin, Y.; Zhu, H. L.; Zhao, L. G., Combined molecular docking, 3DQSAR, and pharmacophore model: design of novel tubulin polymerization inhibitors by binding to colchicine-binding site. Chemical biology \& drug design 2015, 86 (4), 731-745.

14. Lippert III, J. W., Vascular disrupting agents. Bioorganic \& medicinal chemistry 2007, 15 (2), 605-615.

15. Field, J. J.; Kanakkanthara, A.; Miller, J. H., Microtubule-targeting agents are clinically successful due to both mitotic and interphase impairment of microtubule function. Bioorganic \& medicinal chemistry 2014, 22 (18), 5050-5059.

16. Canela, M.-D.; Pérez-Pérez, M.-J.; Noppen, S.; Sáez-Calvo, G.; Díaz, J. F.; Camarasa, M.-J.; Liekens, S.; Priego, E.-M., Novel colchicine-site binders with a cyclohexanedione scaffold identified through a ligand-based virtual screening approach. Journal of medicinal chemistry 2014, 57 (10), 3924-3938.

17. Irwin, J. J.; Sterling, T.; Mysinger, M. M.; Bolstad, E. S.; Coleman, R. G., ZINC: a free tool to discover chemistry for biology. Journal of chemical information and modeling 2012, 52 (7), 17571768.

18. Elseginy, S. A.; Lazaro, G.; Nawwar, G. A.; Amin, K. M.; Hiscox, S.; Brancale, A., Computeraided identification of novel anticancer compounds with a possible dual HER1/HER2 inhibition mechanism. Bioorganic \& medicinal chemistry letters 2015, 25 (4), 758-762.

19. Martineau, M.; McIntosh-Smith, S.; Gaudin, W. In Evaluating OpenMP 4.0's effectiveness as a heterogeneous parallel programming model, 2016 IEEE International Parallel and Distributed Processing Symposium Workshops (IPDPSW), IEEE: 2016; pp 338-347.

20. McIntosh-Smith, S.; Price, J.; Sessions, R. B.; Ibarra, A. A., High performance in silico virtual drug screening on many-core processors. The international journal of high-performance computing applications 2015, 29 (2), 119-134.

21. Morris, G. M.; Huey, R.; Lindstrom, W.; Sanner, M. F.; Belew, R. K.; Goodsell, D. S.; Olson, A. J., AutoDock4 and AutoDockTools4: Automated docking with selective receptor flexibility. Journal of computational chemistry 2009, 30 (16), 2785-2791. 
bioRxiv preprint doi: https://doi.org/10.1101/2021.12.08.471724; this version posted December $9,2021$. The copyright holder for this preprint (which was not certified by peer review) is the author/funder, who has granted bioRxiv a license to display the preprint in perpetuity. It is made available under aCC-BY-ND 4.0 International license.

22. Nguyen, T. L.; McGrath, C.; Hermone, A. R.; Burnett, J. C.; Zaharevitz, D. W.; Day, B. W.; Wipf, P.; Hamel, E.; Gussio, R., A common pharmacophore for a diverse set of colchicine site inhibitors using a structure-based approach. Journal of medicinal chemistry 2005, 48 (19), 6107-6116.

23. Massarotti, A.; Coluccia, A.; Silvestri, R.; Sorba, G.; Brancale, A., The tubulin colchicine domain: a molecular modeling perspective. ChemMedChem 2012, 7 (1), 33-42.

24. Dlugosz, P. J.; Billen, L. P.; Annis, M. G.; Zhu, W.; Zhang, Z.; Lin, J.; Leber, B.; Andrews, D. W., Bcl-2 changes conformation to inhibit Bax oligomerization. The EMBO journal 2006, 25 (11), 2287-2296. 25. Dekan, Z.; Sianati, S.; Yousuf, A.; Sutcliffe, K. J.; Gillis, A.; Mallet, C.; Singh, P.; Jin, A. H.; Wang, A. M.; Mohammadi, S. A.; Stewart, M.; Ratnayake, R.; Fontaine, F.; Lacey, E.; Piggott, A. M.; Du, Y. P.; Canals, M.; sessions, R. B.; Kelly, E.; Capon, R. J.; Alewood, P. F.; Christie, M. J., A tetrapeptide class of biased analgesics from an Australian fungus targets the $\mu$-opioid receptor. Proceedings of the National Academy of Sciences 2019, 116 (44), 22353-22358.

26. Chan, H. H.; Moesser, M. A.; Walters, R. K.; Malla, T. R.; Twidale, R. M.; John, T.; Deeks, H. M.; Johnston-Wood, T.; Mikhailov, V.; Sessions, R. B.; Dawson, W.; Salah, E.; Lukacik, P.; Strain-Damerell, C.; Owen, C. D.; Nakajima, T.; Swiderek, K.; Lodola, A.; Moliner, V.; Glowacki, D. R.; Walsh, M. A.; Schofield, C. J.; Genovese, L.; Shoemark, D. K.; Mulholland, A. J.; Duarte, F.; Morris, G. M., Discovery of SARS-CoV-2 Mpro Peptide Inhibitors from Modelling Substrate and Ligand Binding. bioRxiv 2021 27.Smith, S. A.; Sessions, R. B.; Shoemark, D. K.; Williams, C.; Ebrahimighaei, R.; McNeill, M. C.; Crump, M. P.; McKay, T. R.; Harris, G.; Newby, A. C., Bond, M., Antiproliferative and antimigratory effects of a novel YAP-TEAD interaction inhibitor identified using in silico molecular docking. Journal of medicinal chemistry 2019, 62 (3), 1291-1305.

28. Anukanon, S.; Pongpamorn, P.; Tiyabhorn, W.; Chatwichien, J.; Niwetmarin, W.; Sessions, R. B.; Ruchirawat, S.; Thasana, N., In Silico-Guided Rational Drug Design and Semi-synthesis of C (2)Functionalized Huperzine a Derivatives as Acetylcholinesterase Inhibitors. ACS omega 2021, 6 (30), 19924-19939.

29. Supino, R., In vitro toxicity testing protocols. Methods in molecular biology 1995, 43 (2), 137149.

30. Mooberry, S. L.; Weiderhold, K. N.; Dakshanamurthy, S.; Hamel, E.; Banner, E. J.; Kharlamova, A.; Hempel, J.; Gupton, J. T.; Brown, M. L., Identification and characterization of a new tubulin-binding tetrasubstituted brominated pyrrole. Molecular pharmacology 2007, 72 (1), 132140.

31. (a) Shelanski, M. L.; Gaskin, F.; Cantor, C. R., Microtubule assembly in the absence of added nucleotides. Proceedings of the National Academy of Sciences 1973, 70 (3), 765-768; (b) Lee, J. C.; Timasheff, S. N., In vitro reconstitution of calf brain microtubules: effects of solution variables. Biochemistry 1977, 16 (8), 1754-1764.

32. Aubry, J. P.; Blaecke, A.; Lecoanet-Henchoz, S.; Jeannin, P.; Herbault, N.; Caron, G.; Moine, V.; Bonnefoy, J. Y., Annexin $V$ used for measuring apoptosis in the early events of cellular cytotoxicity. Cytometry: The Journal of the International Society for Analytical Cytology 1999, 37 (3), 197-204.

33. Parrish, A. B.; Freel, C. D.; Kornbluth, S., Cellular mechanisms controlling caspase activation and function. Cold Spring Harbor perspectives in biology 2013, 5 (6), a008672.

34. Syam, Y. M.; Anwar, M. M.; Kotb, E. R.; Elseginy, S. A.; Awad, H. M.; Awad, G. E., Development of Promising Thiopyrimidine-Based Anti-cancer and Antimicrobial Agents: Synthesis and QSAR Analysis. Mini Reviews in Medicinal Chemistry 2019, 19 (15), 1255-1275.

35. Forbes, C. R.; Sinha, S. K.; Ganguly, H. K.; Bai, S.; Yap, G. P.; Patel, S.; Zondlo, N. J., Insights into thiol-aromatic interactions: A stereoelectronic basis for $\mathrm{S}-\mathrm{H} / \pi$ interactions. Journal of the American Chemical Society 2017, 139 (5), 1842-1855.

36. Eswar, N.; Webb, B.; Marti-Renom, M. A.; Madhusudhan, M.; Eramian, D.; Shen, M. y.; Pieper, U.; Sali, A., Comparative protein structure modeling using Modeller. Current protocols in bioinformatics 2006, 15 (1), 5.6. 1-5.6. 30. 
37. Pettersen, E. F.; Goddard, T. D.; Huang, C. C.; Couch, G. S.; Greenblatt, D. M.; Meng, E. C.; Ferrin, T. E., UCSF Chimera-a visualization system for exploratory research and analysis. Journal of computational chemistry 2004, 25 (13), 1605-1612.

38. Pagadala, N. S.; Syed, K.; Tuszynski, J., Software for molecular docking: a review. Biophysical reviews 2017, $9(2), 91-102$.

39. DeLano, W. L., The PyMOL user's manual. DeLano Scientific, San Carlos, CA 2002, 452.

40. Berendsen, H. J.; Postma, J. v.; van Gunsteren, W. F.; DiNola, A.; Haak, J. R., Molecular dynamics with coupling to an external bath. The Journal of chemical physics 1984, 81 (8), 3684-3690. 41. Lindorff-Larsen, K.; Piana, S.; Palmo, K.; Maragakis, P.; Klepeis, J. L.; Dror, R. O.; Shaw, D. E., Improved side-chain torsion potentials for the Amber ff99SB protein force field. Proteins: Structure, Function, and Bioinformatics 2010, 78 (8), 1950-1958.

42. Da Silva, A. W. S.; Vranken, W. F., ACPYPE-Antechamber python parser interface. BMC research notes 2012, 5 (1), 1-8.

43. Wang, W. R.; Wolf, R., J.; Caldwell, JW; Kollman, PA; Case. DA Journal of Computational Chemistry 2004, 25, 1157-1174.

44. Wang, H.; Dommert, F.; Holm, C., Optimizing working parameters of the smooth particle mesh Ewald algorithm in terms of accuracy and efficiency. The Journal of chemical physics 2010, 133 (3), 034117.

45. Humphrey, W.; Dalke, A.; Schulten, K., VMD: visual molecular dynamics. Journal of molecular graphics 1996, 14 (1), 33-38.

46. Martel-Frachet, V.; Keramidas, M.; Nurisso, A.; DeBonis, S.; Rome, C.; Coll, J.-L.; Boumendjel, A.; Skoufias, D. A.; Ronot, X., IPP51, a chalcone acting as a microtubule inhibitor with in vivo antitumor activity against bladder carcinoma. Oncotarget 2015, 6 (16), 14669.

47. Liliom, K.; Lehotzky, A.; Molnar, A.; Ovadi, J., Characterization of tubulin-alkaloid interactions by enzyme-linked immunosorbent assay. Analytical biochemistry 1995, 228 (1), 18-26.

48. Shahali, A.; Ghanadian, M.; Jafari, S. M.; Aghaei, M., Mitochondrial and caspase pathways are involved in the induction of apoptosis by nardosinen in MCF-7 breast cancer cell line. Research in pharmaceutical sciences 2018, 13 (1), 12.

49. Brambilla, E.; Negoescu, A.; Gazzeri, S.; Lantuejoul, S.; Moro, D.; Brambilla, C.; Coll, J.-L., Apoptosis-related factors $\mathrm{p} 53, \mathrm{Bcl} 2$, and Bax in neuroendocrine lung tumors. The American journal of pathology 1996, 149 (6), 1941. 
bioRxiv preprint doi: https:/doi.org/10.1101/2021.12 08.471724. this version posted December 9,2021 . The copyright holder for this preprint (which was not certified by peer review) is the author/funder, who has granted bioRxiv a license to display the preprint in perpetuity. It is made available under aCC-BY-ND 4.0 International license.

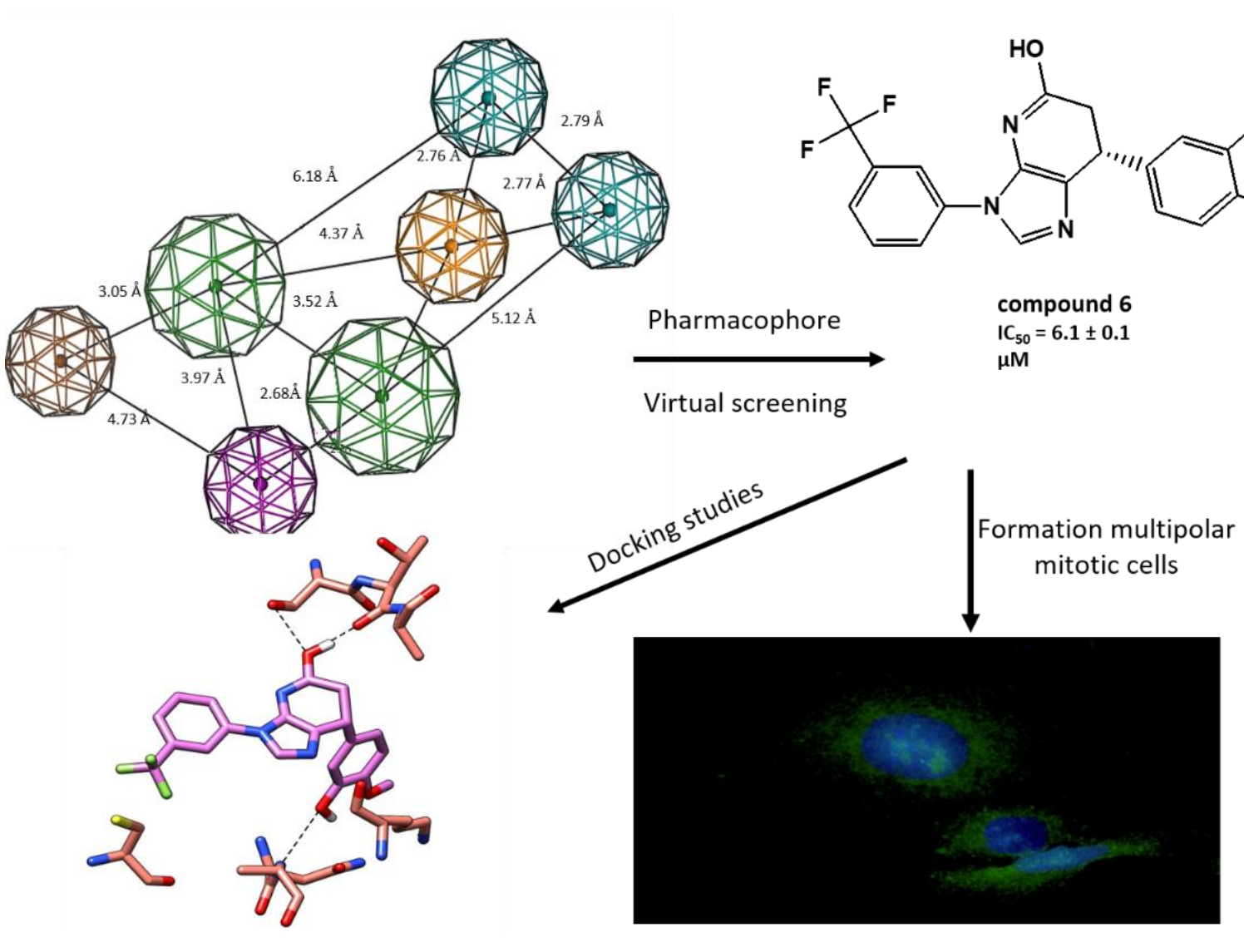

\section{Abstract figure}



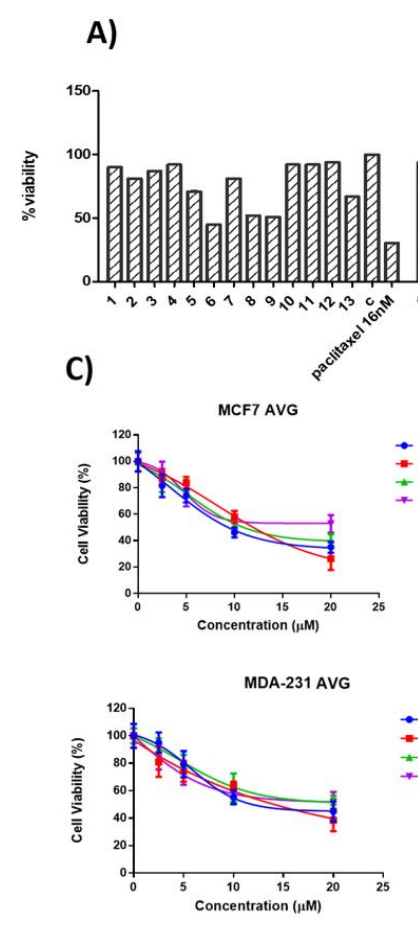

$$
\begin{aligned}
& \square \text { MCF-7 } \\
& \text { MDA-231 } \\
& \square \text { A } 549
\end{aligned}
$$

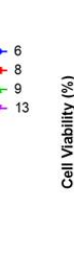

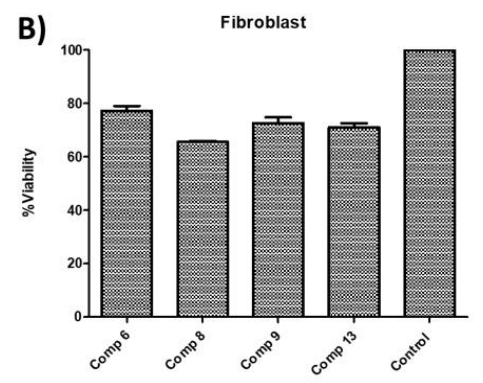

D)

Figure 1. A) Antiproliferative activity of shortlisted compounds identified from the virtual screening against MCF-7, MDA-231 and A549 cell lines. B) Cytotoxic screening of compounds 6, 8, 9 and 13 against FibroblastF180 mammalian cell line showed that compound 6 with highest \% viability which indicates its low toxicity. C) IC 50 of the active compounds 6, 8, 9 and 13 against MCF-7, MDA-231 and A549 cancer cell lines, Paclitaxel was used as positive control. Each result is a mean of triplicate experiments and the mean values and standard error of mean are shown. D) chemical structures of the three best compounds identified by virtual screening. 
A)
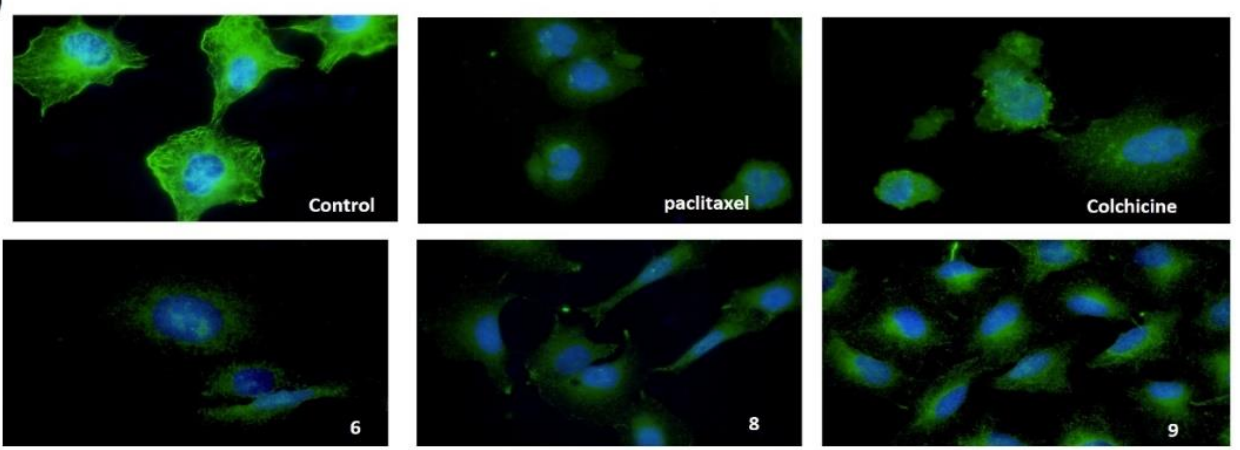

B) 100
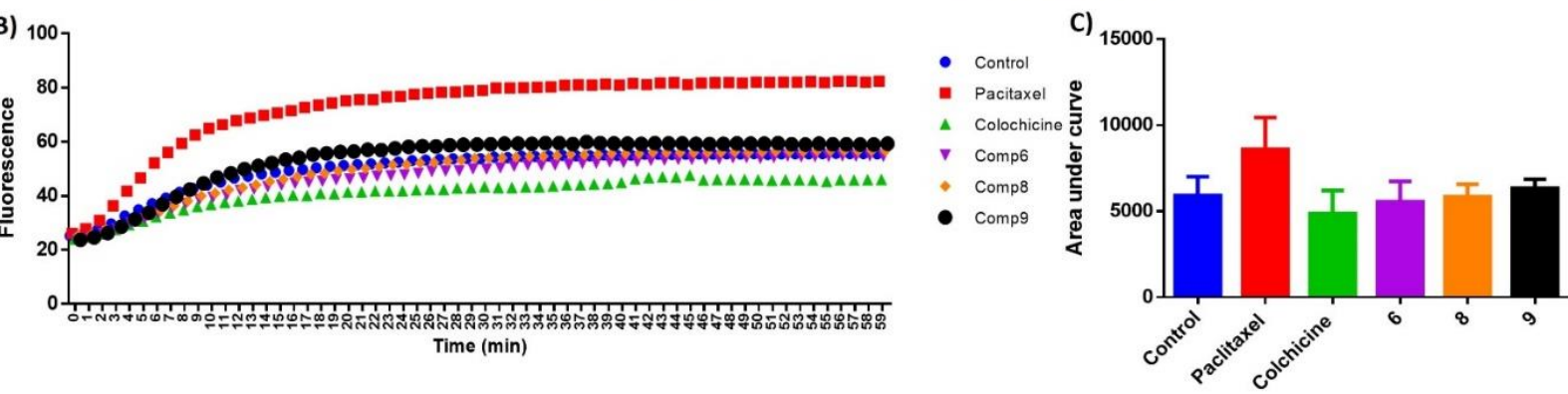

Figure 2. The three compounds 6,8 and $\mathbf{9}$ disrupt microtubule formation in A549 cells. A549 cells were treated for $24 \mathrm{~h}$ with A) DMSO as control, Paclitaxel (14 nM), Colchicine (0.1 nM), compound 6 (16 $\mu \mathrm{M})$, compound $8(13 \mu \mathrm{M})$, compound $\mathbf{9}(9 \mu \mathrm{M})$, then fixed, and stained with anti- $\beta$-tubulin antibody (green) and with DAPI for DNA (blue) to visualize the microtubules. B) Tubulin polymerization of compounds 6, 8 and 9. Tubulin polymerization was monitored by the increase in the fluorescence at $360 \mathrm{~nm}$ (excitation) and $420 \mathrm{~nm}$ (emission) for $1 \mathrm{~h}$ at $37^{\circ} \mathrm{C}$. Paclitaxel and colchicine were used as the positive control while $0.1 \%$ DMSO used as negative control. C) Area under the curve for the tested compounds and positive and negative controls. 


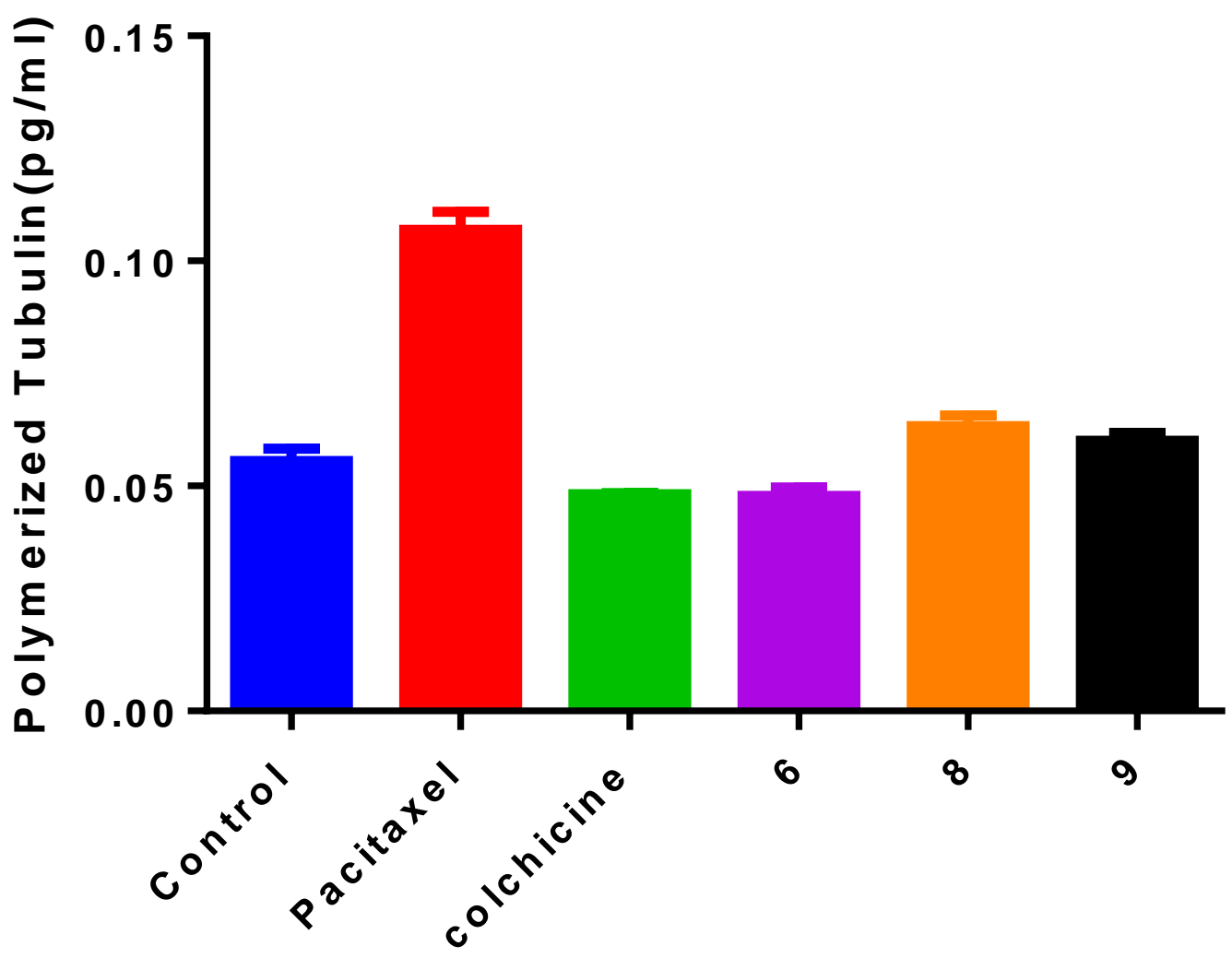

Figure 3. ELISA binding assay. MCF7 cell line treated with compounds 6,8 and $\mathbf{9}$ at their $\mathrm{IC}_{50}$ for $24 \mathrm{~h}$, paclitaxel and colchicine were used as positive controls. The tubulin polymer was extracted, and the quantities of monomeric and polymeric tubulin were measured using ELISA. Compound 6 showed the same effect as colchicine.

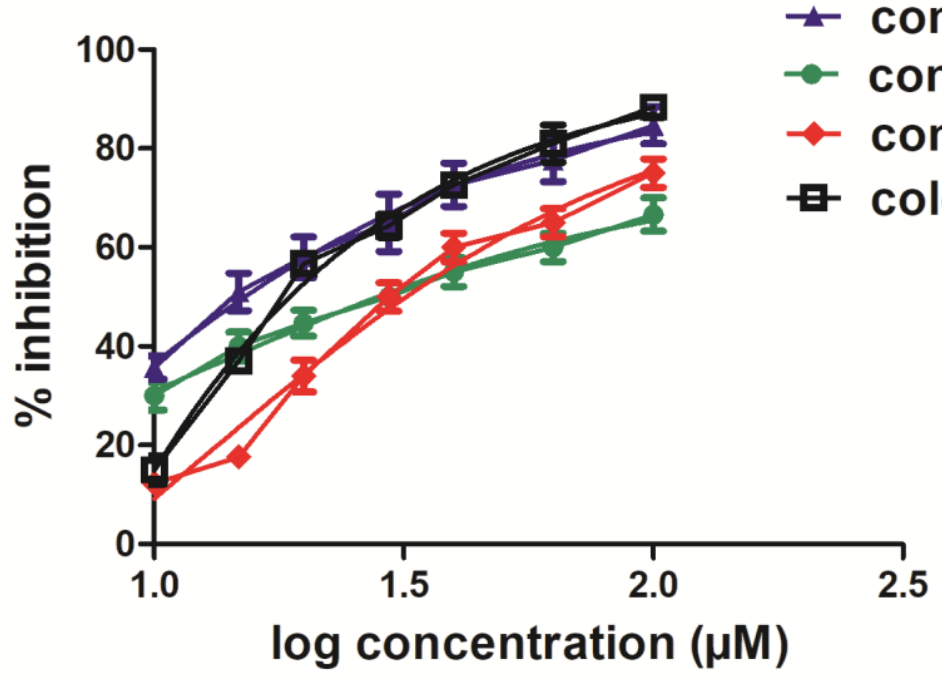

Figure 4. $\mathrm{IC}_{50}$ of the active compounds $6,8,9$ and colchicine in tubulin polymerization assay. Each result is a mean of triplicate experiments, and the mean values and standard error of mean are shown. 

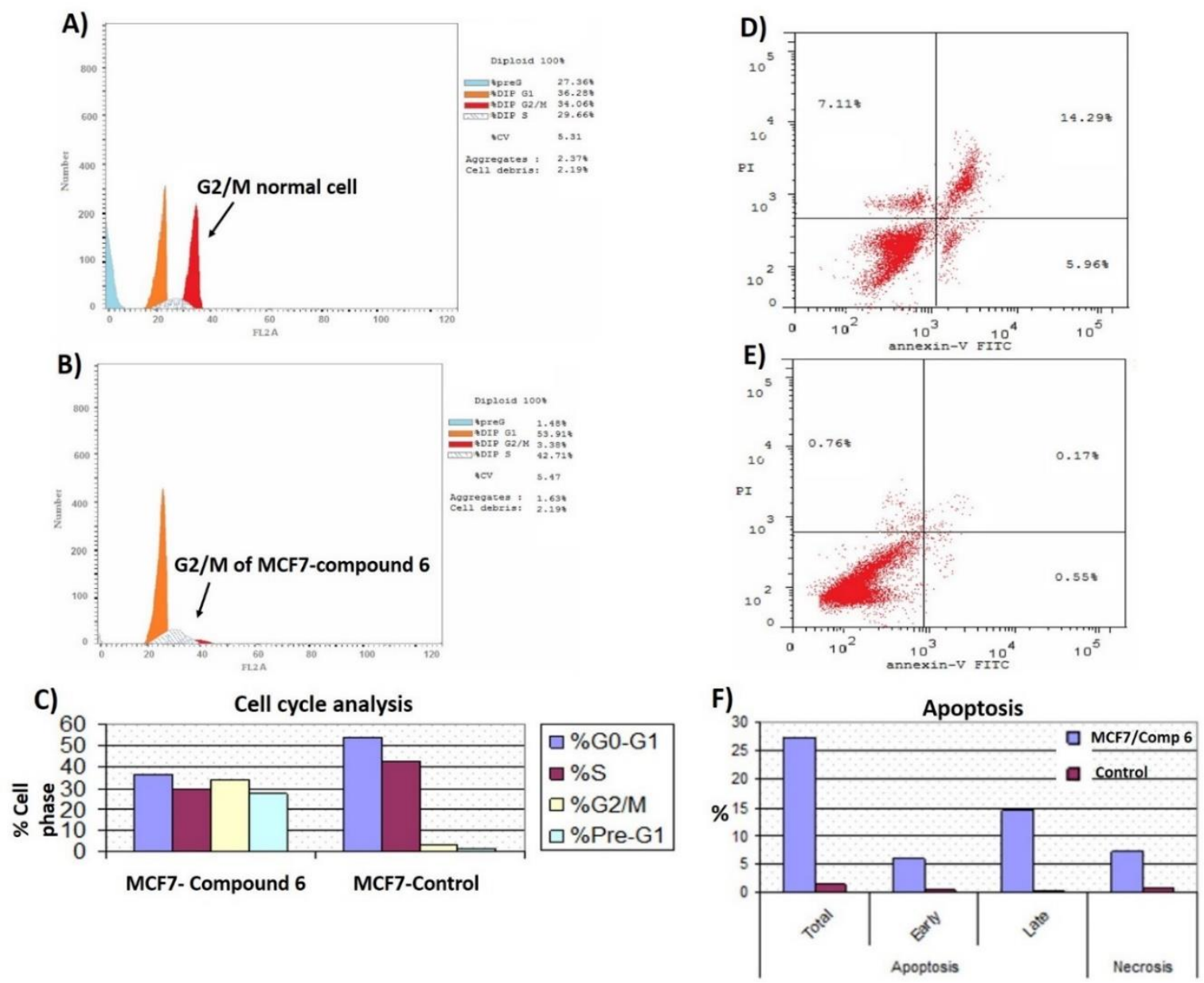

Figure 5. Cell cycle distribution. MCF-7 cells were treated with A) $0.1 \%$ DMSO (B), compound $6(6 \mu \mathrm{M})$ for 24 h. Next, the cells were harvested and stained with propidium iodide, and flow cytometry cell cycle analysis was used to evaluate the cell cycle progression. C) Percentages of cells in the different phases indicate compound 6 arrests the cell cycle at (G2/M). Cell apoptosis D) MCF7 treated with compound $\mathbf{6}$ for $24 \mathrm{~h}$ showed late apoptosis. E) MCF7 treated with $0.1 \%$ DMSO as control. F) Percentage of MCF7 cell apoptosis showed that compound 6 increased both stages of apoptosis with a large increase in late apoptosis. 


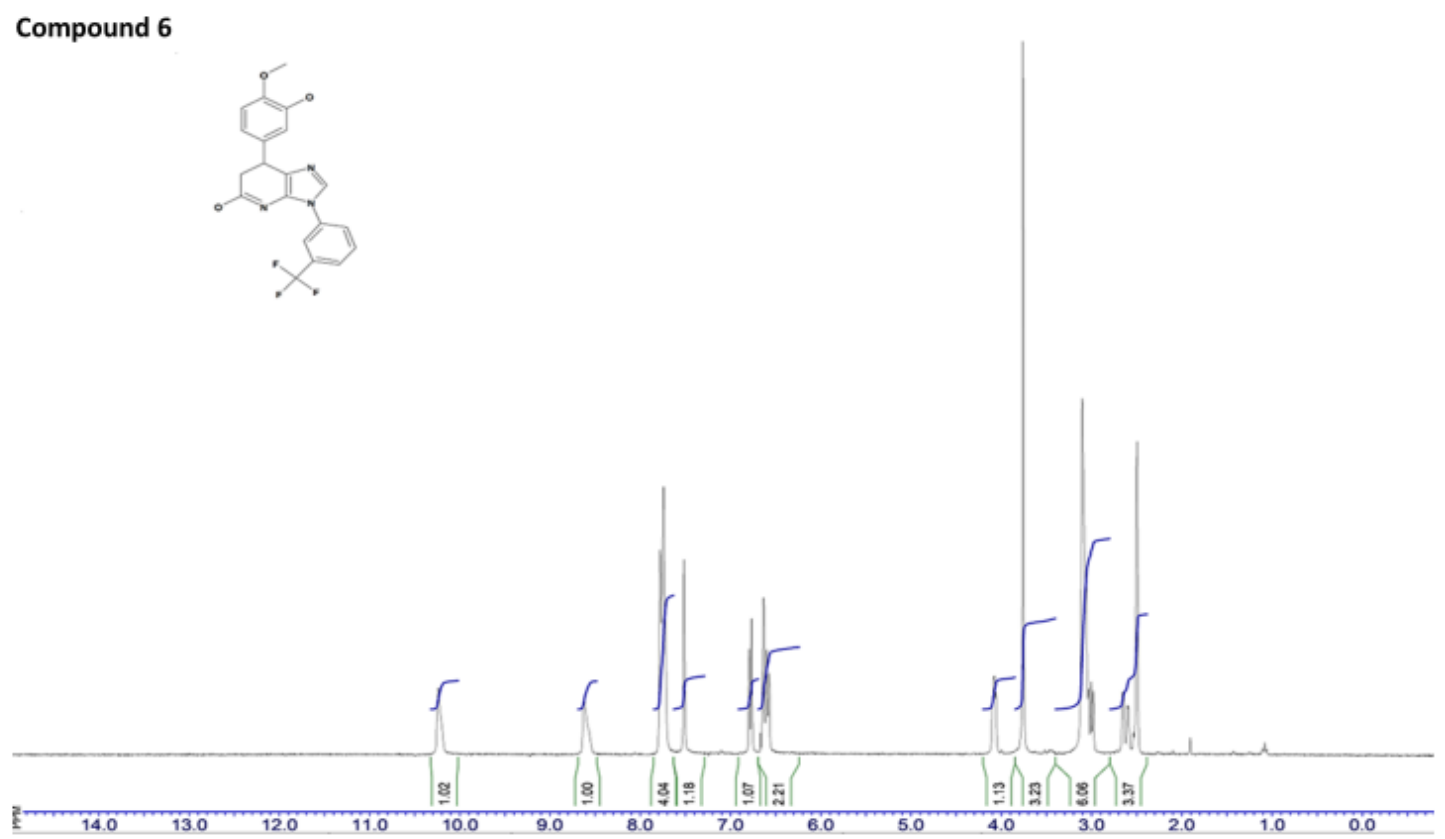

Figure 6: ${ }^{1} \mathrm{H}$ NMR Spectrum of compound 6.

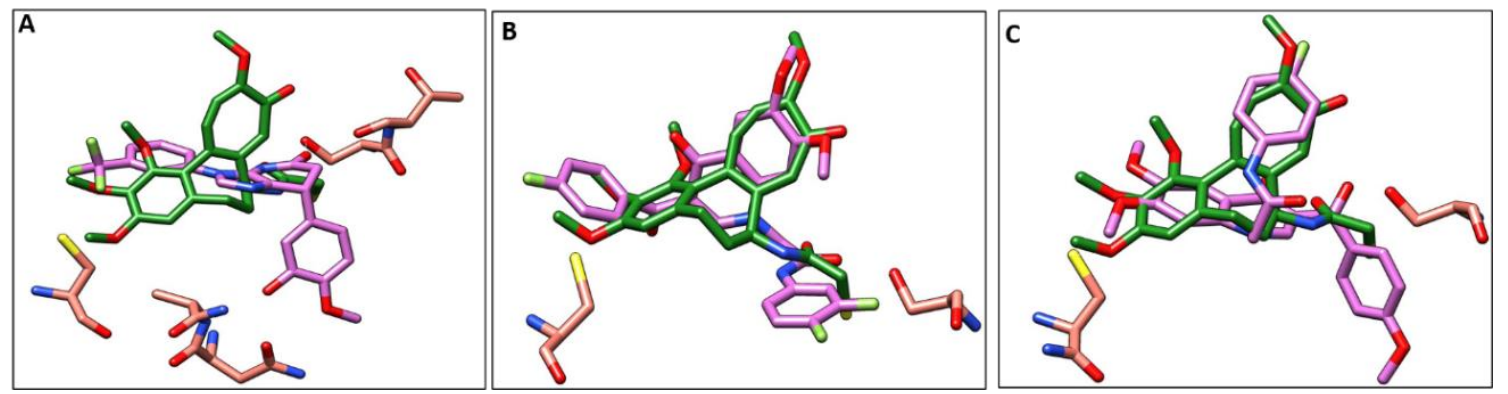

Figure 7. Comparison of the proposed binding modes of compounds 6,8 and 9 into $\alpha / \beta$ interface of tubulin (PDB:1SA0) with DAMA-colchicine binding mode (dark green sticks). A) compound 6 (purple sticks), B) compound 8 (purple sticks) C) compound $\mathbf{9}$ (purple sticks).
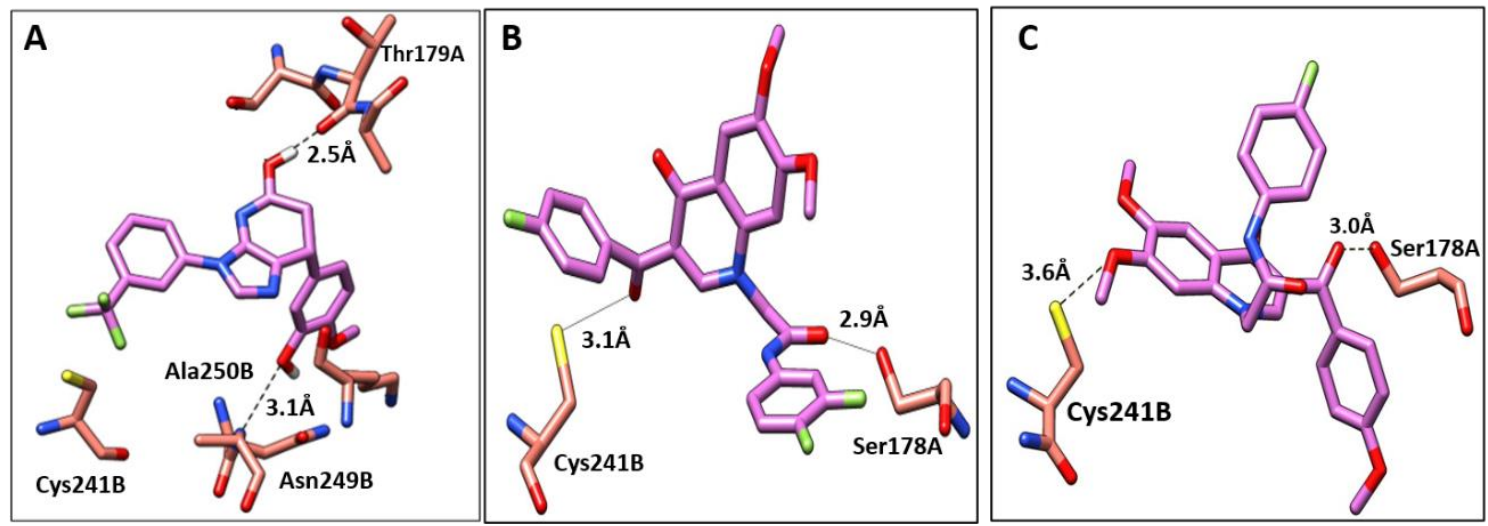

Figure 8. The interactions of compounds 6, 8, and $\mathbf{9}$ with tubulin dimer (PDB:1SA0). A) Compound 6, B) Compound $\mathbf{8}$, C) Compound $\mathbf{9}$, hydrogen bonds are shown as dotted lines. 
Table 1: $I C_{50}$ value of compounds on tubulin polymerization:

\begin{tabular}{|c|c|}
\hline Compounds & $\mathrm{IC}_{50}(\mu \mathrm{M})$ \\
\hline 6 & $6.1 \pm 0.1$ \\
\hline 8 & $13.1 \pm 0.3$ \\
\hline 9 & $12.8 \pm 0.2$ \\
\hline Colchicine & $1.4 \pm 0.02$ \\
\hline
\end{tabular}

${ }^{*} \mathrm{IC}_{50}$ values are the mean of three replicate experiments $\pm \mathrm{SD}$.

Table 2: Determination of Caspase 9, Bcl2, and Bax levels in the MCF7 cells treated with compound 6

\begin{tabular}{|c|c|c|c|}
\hline compounds & Caspase9 $(\mathrm{ng} / \mathrm{ml})$ & $\mathrm{Bcl} 2(\mathrm{ng} / \mathrm{ml})$ & $\mathrm{Bax}(\mathrm{pg} / \mathrm{ml})$ \\
\hline 6 & $13.7 \pm 0.7$ & $2.1 \pm 0.1$ & $207.6 \pm 6.3$ \\
\hline control & $1.8 \pm 0.3$ & $5.7 \pm 0.1$ & $28.8 \pm 1.6$ \\
\hline
\end{tabular}

* Values are the mean of three replicate experiments \pm SD. 